\title{
TOURISM AND ERIK COHEN IN THAILAND: COMPARISONS, IMPACTS, MOBILITIES AND ENCOUNTERS
}

\author{
Victor T. King* \\ Institute of Asian Studies, Universiti Brunei Darussalam, Jalan Tungku Link, \\ Gadong BE1410, Brunei Darussalam \\ e-mail: victor.king@ubd.edu.bn
}

Published online: 15 July 2018

To cite this article: King, V. T. 2018. Tourism and Erik Cohen in Thailand: Comparisons, impacts, mobilities and encounters. International Journal of Asia Pacific Studies 14 (2): 1-38, https://doi.org/10.21315/ijaps2018.14.2.1

To link to this article: https://doi.org/10.21315/ijaps2018.14.2.1

\begin{abstract}
The leading scholar in research in the field of tourism in Thailand is Professor Erik Cohen. Not only has he contributed to the store of empirical material on Thailand on a wide range of tourism-related subjects, but he has been involved in an important series of debates about theories and paradigms in the sociologicalanthropological study of tourism. These debates examine the appropriate concepts to be deployed in understanding leisure activities and the transformations which tourism has set in motion. In tourism studies, there are several key ideas which have preoccupied researchers, many of them in relation to Thailand, to do with cultural "touristification" and commodification; imaging and representation; staging and authenticity; identity and ethnicity; host-guest relations; mediation and tour guides; trajectories of change; sequential typologies; and the tourist gaze. A most recent set of discussions generated by Erik Cohen and Scott Cohen has considered the utility of the sociological concept of mobilities and the problem of Eurocentrism in understanding local-level touristic encounters. The paper will critically review these concepts and provide contextual material on the development of tourism in Thailand during the past four decades. Until recently tourism in Thailand has tended to focus on selected sites along an axis which includes the northern hill or "tribal" regions, Chiang Mai and its environs, the greater Bangkok metropolitan area, and several beach and island resorts in southern Thailand, subjects which Erik Cohen has examined in considerable detail.
\end{abstract}

Keywords: Tourism, comparisons, mobilities, Erik Cohen, Thailand 


\section{INTRODUCTION: SUBSTANTIVE ISSUES}

Thai tourism is a highly diversified, complex, and changing phenomenon, the impact and consequences of which have to be gauged within the wider processes of economic development and social change in Thai society (Cohen 2001a: 28).

This paper provides a critical appreciation of Erik Cohen's sociologicalanthropological research on tourism in Thailand sustained by a close reading of his work in this field and a face-to-face and email dialogue with him during the past three years. ${ }^{* *}$ It is structured around Cohen's observation that his research did not stem from "a long-range research project"; rather it comprised "shifting and expanding interests" which "developed over the years in a process of interaction between theoretical concerns and research findings" (Cohen 2001b: ix; Cohen 2001c). In much of his work, his approach adopted appropriate concepts to address the topic or issue under investigation; there was no overarching theory that was pursued single-mindedly. The most important biographical appreciation of Cohen's work has been provided by Scott Cohen (2013) who has also co-authored several theoretically significant publications with Erik Cohen since 2012 (see, for example, Cohen and Cohen 2012a, 2012b, 2015a, 2015b, 2015c; and Cohen, Cohen and King 2016). Scott Cohen indicates that up until his 2013 publication there was "only piecemeal biographical information available about him [Erik Cohen] in the public domain" (Cohen 2013: 104), though there had been some informative autobiographical exposures in Erik Cohen's own work (see, for example, 2001b, 2007a: 50-59, 2012a), and useful material in Nelson Graburn's brief appreciation (2004: 94-95). The concluding comments of Scott Cohen on Erik Cohen's work set the scene for my current project: "Encapsulating Erik Cohen's contribution to the advancement of the field of tourism studies in a few words is a problem, for his work has been incredibly varied, covering so many ways in which tourism interfaces with the contemporary world" and "Professor Erik Cohen's work has been absolutely fundamental to the development of tourism studies and its dissemination from both sociological and anthropological perspectives" (Cohen 2013: 109, 110).

The crucial concerns for social scientists since the second half of the 1970s have been the socio-cultural interactions between visitors, tourism intermediaries and local communities, and their respective responses, and their interpretations of these complex encounters (Cohen indicates that his early interest in hill tribe tourism in the 1970s was in "touristic interactions," especially between tourists, "jungle guides" and ethnic minorities [2001b: 
x-xi, 1982a, 1983a, 1985a, 1989a]). In addition, Cohen was interested in the organisational forms, interactions, and the content of and the processes involved in a wide range of tourism activities: touristic engagement, emerging tourisms and resulting touristic differentiation in attractions, sites and events (1972, 1979a, 1979b, 1979c, 1983b, 1984a, 1987a, 2001a, 2001d, 2001e, 2008a; and see Dann and Cohen 1991); as well as the socio-economic backgrounds, experiences and motivations of tourists, and their categorisation (1974, 1979a). Cohen also developed an ethnographic interest in "hill tribe tourist art" and the need "to place this within the wider context of cultural, economic and political trends in the region" (2001b: xi, 2000, 1983a, 1989b, 1989c, 1993a, 1996a), and imaging and representations of peoples and sites in advertisements, brochures, greetings cards, postcards, and popular and scientific literature (1992a, 1992b, 1993b, 2001d). He also explored the ways in which tourism becomes implicated in cultural politics and identity formation in the encounters between the nation-state and its constituent ethnic groups (1983c, 1992a, 1993b, 2008a). More generally, Cohen examined the social, cultural economic, political and environmental consequences of tourism $(1978,1988 \mathrm{a}$, 2007b, 2008a). He has also addressed a range of seemingly disparate elements and events in tourism in Thailand: the breadth of his interests is impressive, from Chinese vegetarian festivals and spirit possession (2001f, 2009a, 2012b), medical tourism (2010a), the symbolic and practical role of animals in tourism (2009b, 2010b, 2012c), tourist jokes (2010c), golf tourism (1995a), tribal costume (1988b), spirit houses (2014a), backpacking (2004a), pilgrimage (1992c, 2004b), floating markets (2016a), tourism-related crime (1996b, $1997)$, tourist murders $(2008 \mathrm{~b}, 2016 \mathrm{~b})$, tourist fatalities in natural disasters (2009c), tourism crises (2010d, 2012d; Cohen and Neal 2010), urban heritage (2014b), tattoo tourism (2013) and food tourism (Cohen and Avieli 2004). Amidst this diversity three central interests appear to structure Cohen's work: (1) general conceptual and theoretical papers in the sociology-anthropology of tourism; (2) various aspects of tourism in Thailand; and (3) critical case studies of ethically problematic issues such as the Koh Tao tourist murders.

He has brought together many of these concerns in his collected essays: Thai Tourism: Hill Tribes, Islands and Open-ended Prostitution (2001a, 2001b, 2001c [1996]) and Explorations in Thai Tourism: Collected Case Studies (2008a). The first collection, as the sub-title suggests, comprises 14 papers, grouped into three categories: hill tribe tourism in northern Thailand; "vacationing" or island tourism in southern Thailand; and sex tourism in Bangkok. Cohen also refers to these three categories in the introductory chapter to his second collection of essays and to several other researchers who 
have explored facets of these three different geographically-located kinds of tourist encounter (Cohen 2008a: 1).

However, in the successor volume, Cohen dwells on the diversity of tourism and its progressive differentiation in Thailand as a mature, continuously developing destination; he suggests that up the 2000s research had failed to address adequately this diversity (Cohen 2008a: 1-2). In an important respect, it is a continuation and elaboration of the framework which he devised in his first volume to capture the dynamics of tourism development (Cohen 2001a, 2001b; and see Cohen 1995b, 2001d). The maturing and diversification of tourism is set within the context of the wider socio-cultural, economic and political relationships at work in Thailand, as well as the beneficial and detrimental effects of a rapidly globalising service industry (Cohen 2001a: 24-28). He has demonstrated admirably this changing response to the demands of tourism, both domestic and international, in his more recent examination of the "permutations" of Thailand's "floating markets" and his presentation of a "sequential typology" of continuously active, revived neo-traditional and new markets (Cohen 2016a: 65-78).

Therefore, in the second collection comprising reprinted publications or revised papers in the period 2005 to 2007 , he ranged over several issues, some of which can be expressed as "emerging" tourisms, including tourism and disaster (specifically the tsunami in southern Thailand); environmental change; backpacker tourism in Pai, northern Thailand; elephants and tourism; medical tourism and the institution of the "hotel-spital" (and see, for example, Cohen 2010a); and the post-modernisation of (mythical) events, fantasy sites (the American West and cowboy towns in Thailand) and greetings cards which meld Western and Thai themes. Interestingly, what he suggests, in his introduction to this collection, is that the diversity of his case studies has required a set of diverse concepts, echoing his earlier comments on engaging with analyses appropriate to the task in hand. Therefore, the studies "lack a common theoretical framework" (Cohen 2008a: 2, 15-20). I will return to these matters later, specifically in considering Erik Cohen's and Scott Cohen's subsequent discussion of a "mobilities paradigm" in tourism research (see, for example, Cohen and Cohen 2015a, 2015b, 2015c).

In his 2008 overview Cohen refers to several macro-sociological studies which address processes of tourism-generated change and development in Thailand, but, even with full recognition of the importance of these contributions (for example, Elliott 1983; Forsyth 1995; Kontogeorgopoulos 1998, 1999; Meyer 1988; Parnwell 1993; and Peleggi 1996. See also Li and Zhang 1997; McDowall and Wang 2009; McDowall and Ma 2010), it has been 
Cohen's work, in its comparative range, depth of detail and innovation which occupies centre-stage. My only observation in this regard is that Maurizio Peleggi has also made a significant contribution to our understanding of heritage in Thailand (see, for example, Peleggi 2002, 2007, 2017).

\section{TOURISM DEVELOPMENT IN THAILAND}

Cohen argued in the 1990s that "Thailand is by now, even from a global perspective, a mature tourist destination; it is certainly one of the touristically most developed countries in the Third World" (Cohen 2001a [1996: 1]; see 2008a: 3). Its journey towards modern tourism activities began primarily in the 1960s in the context of the American use of Thailand for its military bases and as a place for G.I. rest-and-recreation (R\&R) during the Indochina wars. Field Marshal Sarit Thanarat (1957-1963) established the foundations for international tourism in his open-door policy on foreign investment and the development of a national infrastructure, supported by significant levels of American military aid between 1965 and 1975 (Kontogeorgopoulos 1998: 226). The Tourist Organization of Thailand (TOT) was established in 1960 during the Sarit regime, later to become the Tourist Authority of Thailand (TAT) in 1979 (TAT 2017). Landmarks in the development of tourism in Thailand were Visit Thailand Year (1980 and 1987), Amazing Thailand (19981999), Unseen Thailand (2003), Thailand Grand Invitation (2007), Thailand Talk to the World (2007) to coincide with His Majesty Bhumipol Adulyadej's 80th birthday, TAT's 50th Birthday (2010), Amazing Thailand It Begins with the People (2013-2014), Discover Thainess (2015), and Unique Thai Local Experiences (2017). During the early 2000s Prime Minister Thaksin Shinawatra's administration formulated a more comprehensive tourism policy and intensified the promotion of tourism, restructuring and upgrading the industry to ensure that it became "the tourism capital of Asia"; and although there were some post-Shinawatra policy modifications, broadly speaking the TAT continued the direction set by his government (Cohen 2008a: 4).

What is most significant in understanding the trajectories and character of tourism in Thailand is that a large segment of activity is based on domestic tourism (Cohen 2008a: 2). Even in international tourism, the overwhelming numbers of foreign visitors come from neighbouring ASEAN countries and East and South Asia. Of the top 20 visitor sources, 13 are Asian. In 2016 Thailand received 32.59 million visits generating some 2.52 trillion baht for the national economy (Wikipedia 2017). Of these, 8.644 million were from ASEAN, the main source was Malaysia (3.534 million) and then in order Laos, 
Singapore, Vietnam, Cambodia, Indonesia, Myanmar and the Philippines. Of other Asian tourists in the top 20 over 14 million came from other Asian countries: China provided 8.757 million of these, then South Korea, Japan, India, Hong Kong and Taiwan.

Therefore, two-thirds of tourists to Thailand in 2016 were Asian. Moreover, visitors to many of the major sites in Thailand are either domestic tourists or Asians from neighbouring countries. Of non-Asian tourists in the top 20 Russia was first and then the United Kingdom, United States, Germany, Australia and France amounting to 5.434 million visitors; this is not an insignificant number, amounting to approximately $16-17$ percent of tourists; and they tend to focus on well-defined and promoted tourist sites: beach resorts in southern Thailand, Bangkok and its shopping, night-life and heritage, and Chiang Mai, hill tribe areas and nature. In addition, the Thai government and the TAT began to address the importance of domestic tourism with the rapid growth of a Thai middle class and an increase in leisure time and disposable income, especially significant for those tourist attractions around the major urban centres, particularly in the Greater Bangkok Metropolitan Area. Therefore, the major features of tourism in Thailand, as Cohen emphasised, is the need to conceptually address the importance of encounters among and between Asians and between Thais, with less preoccupation on Asian-nonAsian interactions (which was a feature of earlier empirical and theoretical studies on tourism). Cohen's later work demonstrates this increasing shift to the "domestication of tourism" (2008a). In his detailed ethnography of the Chinese vegetarian festival in Phuket in the 1990s he demonstrates the process by which a ritual becomes a "public spectacle" and the interest shown in this by Thai and foreign Chinese believers and visitors in search of an "authentic" Chinese festival (Cohen 2001f). This fact must also be linked with the increasing evidence of regionalisation in tourism (Wall 2001: 316, 321, 323).

I have already referred to Cohen's attempt to capture this process of regionalisation but also the changing transformations and maturation in Thai tourism (Cohen 2001a, 2001b, 2001c, 2001d). He identifies "four principal trends of change" (2001a: 4), comprising (1) "massification: from personalised to impersonal tourism" from the 1970 s, with the development of transport, communications and tourism infrastructure; (2) "expansion: from centralised to dispersed tourism" away from the main tourism hubs of Bangkok, Phuket and Chiang Mai to such destinations as Chiang Rai, Haadyai, Mae Hong Son, Pai, Kanchanaburi and several southern islands such as Krabi and Trang; (3) "heterogeneisation: from homogeneous to diversified tourism" to meet the needs of an increasing range of tourists: European and American, 
to Japanese, Chinese, Korean, Taiwanese, Malaysian, Singaporean, Russian and Middle Eastern, and to move from sex tourism to ecotourism, historicalheritage-cultural-ethnic tourism, vacationing, medical tourism and theme parks (and see Cohen 2008a: 1-21); and (4) "regionalisation: from isolation to regional integration" in that Thailand plays a pivotal role in the coordination, supply and support of tourism to the Lao PDR, Cambodia, Myanmar and Vietnam (2001a: 4-14). Of course, there would need to be some elaboration of these stages in regional comparative terms in that some destinations elsewhere in Southeast Asia have not been subject to "massification"; some sites fail in competition with others; other sites experience different forms of tourism which merge into longer term sojourning and retirement; in my view, there is no general model or template of regionalisation in ASEAN. Following Cohen, Thailand as a mature tourism market, which has been open to commercialisation and international tourists, has certain distinctive features. Surrounded by nation-states which were relatively closed to tourism until the 1990s, the regionalisation of tourism has been a relatively recent phenomenon in that Thailand has become a fortuitous hub and a springboard for movement into nearby mainland countries. His model, though it works well for Thailand and its neighbours, does not work so well for, say, the movement of certain categories of tourists and visitors between Malaysia, Singapore, Brunei Darussalam, Indonesia and the Philippines, which importantly, unlike Thailand, were subject to colonialism (see, for example, King 2016a).

If we reorient ourselves to domestic tourism and the regular movement of Southeast Asians across borders within the region for a variety of purposes prior to the development of mass tourism, then we shift our frames of reference. Thailand, as a state which was not subject to formal European colonisation and decolonisation, also gives expression to different cross-border experiences from those in the island world of Southeast Asia which were subject to colonialism and the creation of independent nation-states whose borders and territories were negotiated and reconfigured, processes which in turn influenced the kinds of cross-border movements established before the regionalisation of tourism began in earnest from the late 1980s.

In regard to the increase in mass tourism, Cohen also points to a "ubiquitous process" in Thailand, whereby "natural attractions" or "preexisting environmental, cultural and historical sites and events, which appear, or are promoted in the language of tourism... as "authentic," "pristine" or "untouched," in alleged sharp contrast to the prevailing state-of-affairs in the contemporary West have to be adapted or protected to cope with increasing tourism pressures (Cohen 2001d: 155). At the same time, newly-contrived 
attractions appear to "enhance the attractiveness of the destination" and to either "deflect tourists from the declining natural attractions" or to serve as substitutions for "natural" attractions (Cohen 2001d). These comprise such sites as theme and amusement parks, wildlife and bird parks, craft and ethnic villages, and new festivals and events; these may over time become "naturalised" and incorporated into local cultures and ways of life and presented as "traditional" or part of local "ethnic identities" (Cohen 2001d: 156-170). He explores these innovations in more detail in subsequent work (Cohen 2008a). An interesting suggestion, which has supporting evidence in recent developments in mainland Southeast Asia is that "regionalisation of mainland Southeast Asian tourism... may well reinforce the process of Thailand's touristic transition, with Thailand as a country specialising in the provision of facilities and contrived attractions while the newly opened countries and the remote border regions of Thailand provide fresh natural environmental and cultural attractions" (Cohen 2001d: 171).

\section{EARLY SOCIOLOGICAL-ANTHROPOLOGICAL WORK}

Tourism has attracted increasing sociological-anthropological attention from its birth as a legitimate subject for study some four decades ago because of its "inexorable links with culture" and its engagement with "cultural otherness" (Burns 1999: 33; Yamashita et al. 1997: 14). These concerns resulted in the formulation of such concepts as "staged authenticity," "tourism as a sacred journey" and "cultural commoditisation." Above all tourism was conceptualised as a dynamic socio-cultural process which increasingly "impacts" on those communities living and working in and around tourist sites and becomes incorporated into processes of cultural change and identity formation at the local and national levels.

However, looking back at the mid- to late-1970s, which marked the birth of sociological-anthropological studies of tourism, Thailand did not feature to any extent: in the work of such scholars as Graburn, in his studies of ethnic and tourist arts as carriers of symbols and messages, and his concept of tourist travel as a "sacred journey" (Graburn 1976, 1977 [1989]; see Cohen 1985b); in MacCannell's thesis on the "leisure class" and the "homelessness" of the "modern" (MacCannell 1973, 1976); in McKean's formulation of the notions of "economic dualism" and "cultural involution" in his study of tourism in Bali (1973, 1976, 1977 [1989]); in Smith's categorical division between "hosts and guests" (1977 [1989], 1989); and in Wood's work on tourism and underdevelopment, his reconceptualisation of the relationships between 
tourism and culture, and his critique of Western ethnocentrism and Westernderived normative categories (Wood 1979, 1980, 1993). In these early studies Thailand does not play a formative role either as case material or in early conceptual development.

The neglect of this mature tourism destination was confirmed in Smith's widely acclaimed Hosts and Guests: The Anthropology of Tourism (1977 [1989]). Significantly there were chapters on cultural tourism in Bali (McKean 1977 [1989]) and ethnic tourism in the Toraja Highlands (Crystal 1977 [1989]), but no attention to Thailand. Perhaps this was a consequence of the differences in tourism in these two destinations in the 1960s and 1970s. Anthropologists could comfortably study cultural and ethnic tourism in Indonesia, in that these were embedded in the relationships between minorities and the nationstate, but they were less at ease in addressing sex tourism in Thailand. It was much later in Indonesia that social science shifted its attention from cultural and ethnic tourism to sex tourism (Dahles 2009). In the case of Thailand, prostitution was made illegal in 1960 and was a problematical area for social science research (Cohen 2001a: 3). The combination of sexual license with leisure activities seemed problematical for anthropologists and sociologists to negotiate even into the 1990s.

For example, tourist-oriented prostitution and the complex socio-cultural encounters between foreign tourists and young Thai women was not addressed to any degree until Cohen's exceptional studies (Cohen 1982b, 1984b, 1986, $1988 c, 1993 c, 2003)$. Cohen says in his reflections on this field of study that it was "a subject of considerable public attention and controversy, but on which little empirical research had been undertaken" (Cohen 2001b: xi). Indeed, when Cohen was developing his concept of open-ended tourist-oriented prostitution (Cohen 1993c) and the ambiguous relationships between Thai hosts and falang guests (Cohen 1982b, 1986) there were very few studies of the consequences of the touristic commercialisation of sexual relationships (but see Keyes 1984; Khin 1980; Phongpaichit 1982 and Senftleben 1988). Manderson explains this neglect, in her examination of the touristic representations of women and sexuality in Thailand. "Sex and tourism share marginal status within the social sciences. The disinclination of anthropologists, among others, to study the latter has been in part a wariness of the uncomplimentary analogy between tourism and anthropological practice, in part also because of tourism's association with leisure, hence the implicit triviality of its study as well as pursuit... For sex, too, uncomfortable sets of personal associations pertain" (1995: 307; 1992; and Crick 1996). In my view, it was unlikely at that time that the major Western social science funding bodies, given their ethical concerns, would 
have supported ethnographic research on sex tourism, though increasingly the issue of sexually transmitted diseases and AIDS attracted attention from NGOs and funders concerned about the need to encourage policy changes in developing countries (Cohen 1988c; Leheny 1995). Indeed, the title of one of Cohen's papers, "sensuality and venality," in exploring the fuzzy boundaries between prostitution and open-ended hosting, was not officially welcome in Thailand at that time (Cohen 1987b).

In fact, Cohen's first major contributions to research on Thai tourism did not primarily address sex tourism, but rather, examined the kinds of tourism acceptable in professional anthropological circles: firstly, hill tribe tourism, ethnicity and ethnic arts in the uplands of northern Thailand (Cohen 1982a, 1983a, 1988b, 1989c, 1992a, 1992b); and then "vacationing" or beach tourism in the southern islands of Thailand (Cohen 1982c, 1983b, 2001e).

\section{COHEN'S CONTRIBUTIONS}

\section{General Perspectives and Comparisons}

I have undertaken a brief review of some of Cohen's contribution in previous publications (King 2009: 46-53, 63-64; 2015a: 507-519; Hitchcock, King and Parnwell 2009a: 19-20; King 2015b). In this present evaluation of his work, I have attempted to update the review and reconsider some of his more recent conceptual and empirical contributions. In his early studies, he characterised tourism in Thailand in terms of a complementary dualism: "eroticism" and "exoticism" and the striking oppositions between the profane and the sacred, "brothels" and "temples," and "pilgrimage" and "prostitution" (Cohen 2001a: $2-3,2004 b)$. The study of tourism, like sociological-anthropological studies more generally, is replete with these dual categorisations: work and leisure, every-day and extraordinary, home and away, authentic and inauthentic, reality and fantasy, hosts and guests, nature and culture, international and domestic, global and local, tradition and modernity, tradition and invention, and hot and cool, as well as the perspectives which cluster around Western/Eurocentric/ Orientalist and "alternative/non-Western" approaches (King 2015a: 508-509).

In the late 1970s, Cohen, in his first major study of tourism in Thailand, viz. hill tribe tourism, drew our attention to a significant issue: the academic literature on the social and cultural "impacts" of tourism had failed "to discuss systematic differences between types of tourists or types of communities" (2001h: 115 [1979c]). He identified an absence of "the middle range of systematic comparative studies which are specifically designed to examine 
the differential impact of given types of tourism under different sets of conditions." Ambitiously he addressed this lack of a comparative perspective by examining the differential effects of "tribal village tours" and "jungle tours" on five communities from three different ethnic groups (Meo [Hmong], Lisu and Akha). He identified three variables - the place of tourism within the local socio-economic context, the nature and organisation of the tourism enterprise, and tourist-villager interactions (Cohen 2001h: 118-119).

Cohen's argument was based on the premise that tourism should be understood in terms of interrelated processes and not as "an isolated event"; it generates consequences for the host communities which can be anticipated or intended, as well as "unexpected and often not desired" (Cohen 2001h: 113). This became a persistent theme in his later work. Cohen concluded that though some communities may have been "spoilt" by tourism, and are no longer as "authentic" as they used to be, tourism has not had a significantly disruptive impact on village life (Cohen 2001h: 140). What is remarkable is that, although some comparative research has been undertaken in Southeast Asia since Cohen's study, there has been very little in the way of country-wide let alone region-wide comparison (see, for example, Cohen 2008a: 20-21). Therefore, Cohen remains something of an exception in his wide-ranging and systematic studies of the different dimensions of tourism in Thailand (2001c, 2008a), although there have been several edited collections which have drawn attention to some of the similarities and differences in tourism experiences both within and across countries in Southeast Asia (see, for example, Hall and Page 2000; Picard and Wood 1997; Teo, Chang and Ho 2001; Hitchcock, King and Parnwell 1993, 2009a, 2009b, 2010; Hitchcock and King 2003).

Cohen's comparative study and his related papers on hill tribe tourism in Thailand (1982a, 1983a, 1983c, 1985a, 1989a, 1992a, 1993a, 1993b, 2001h [1979c]) address themes which continue to play a vital role in sociological-anthropological studies. A major concern is, in Cohen's terms, the "impacts" of tourism on local communities. This has long been a central preoccupation of research, although the ways in which host-guest interactions and their consequences have been conceptualised have changed since Cohen undertook his early studies, particularly the notion of tourism as an external force "impacting" on local communities (Wood 1993; Picard 1996). Rather than seeing the social effects of tourism on local cultures as "destructive," "negative" or "inimical," on the one hand or "negligible," "moderate," "more beneficent" or "positive" on the other (Cohen 2001h [1979c]: 113-121; 140-144), researchers have more recently moved beyond this "normative" framework to one which conceptualises "culture" and "tradition" in symbolic 
terms, as a "hybrid entity," as "constructed" and "reconstructed," "invented," "improvised," "manipulated," "relational," "historically unfinished" and "consumed," and tourist hosts as "cultural strategists" (Wood 1993: 58-60; 64-66; Erb 2000: 709-736; Hitchcock 1999: 17-32; Picard 1996: 190-200; Yamashita 2003: 4).

Cohen's earlier work on "impacts" was carefully qualified in its assessment of the costs and benefits of tourism in different contexts in northern Thailand. But, in my view, he had not yet embraced fully the notion of "traditions" as represented and attributed symbolically, though this perspective was prefigured in his rethinking of the sociology of tourism (Cohen 1979b). Even after Wood's re-conceptualisation of "cultural change" in the 1980s, in the second edition of Smith's Hosts and Guests (Smith 1989), the editor keeps to a concept of change as "impact" and as "beneficial" or "damaging;" the preoccupation is with the encounter between "foreign" guests and "domestic" hosts. This remained a central but problematical issue in tourism research in the 1980s and 1990s; in other words, the increasing importance of domestic tourism and intra-Asian encounters had still not come firmly into focus.

\section{Authenticity and Authentication}

Arising from his earlier empirical work on hill tribe tourism, Cohen addressed the complex concept of "authenticity" in evaluating the cultural effects of tourism. Addressing hill tribe trekking, he examined the touristic search for the "primitive" and "remote" as an opportunity for the "staging of authenticity" (Cohen 1989a: 30). He argued post-normatively that conceptions of what is "genuine" and "invented" or "false" are "socially constructed" (Cohen 1988a). He reconsidered MacCannell's concept of "authenticity" and the view that tourists were in search of original "social" experiences, in their quest, beyond their every-day, fragmented, alienated, "inauthentic" lives to recover a sense of personal and social wholeness and structure (MacCannell 1973, 1976). In his theoretical discourse on "the structure of modern consciousness" (Cohen 1989a: 32) MacCannell also developed the related notion of "staged authenticity" in which tourist hosts, agencies and guides, in promoting the attractiveness of their tourist assets, construct seemingly authentic experiences to seduce their guests (1973: 602-603). The tourist becomes ensnared in a contrived "tourist space" which presents "unchanging native traditions," "pristine cultures" and "exotic communities."

"Staging" comprises two main kinds, although these are interrelated and complementary: "substantive" where an attraction is altered or created afresh, and "communicative" where it is either presented in tourist promotional 
literature without necessarily interfering with the attraction or site thus advertised, or where the attraction is interpreted as authentic by tour guides and intermediaries (Cohen 1989a: 33-35). From this interest Cohen also addressed a neglected element in tourism research, that of the complex and changing roles of mediation, interconnection and representation through the agency of the "jungle guide" (Cohen 1982a) or "tourist guide" (Cohen 1985a). The guide, as a crucial intermediary, is regularly engaged in the process of "authentication." Cohen's study of "jungle guides" is an interesting case of mediation because, at least in the initial stages of tourism development, the Thai state did not assume a leading role. Rather it was the interaction between "alternative" tourists (young travellers in search of "authentic" experiences) and "local entrepreneurs" which generated hill tribe tourism (1989a: 31). Cohen also noted that the provincial authorities had not encouraged jungle tourism, but "half-heartedly acquiesced to its spontaneous development" (1982a: 234). However, once it had emerged, the authorities began to intervene to regulate and professionalise the "marginal" occupation of jungle guiding. Cohen stressed the importance of the personal qualities of the guides, their charisma, experience, reputation and linguistic abilities as well as the activities of a small group of tour companies as agents in developing and presenting "images" of the hill tribes (1989a: 59-61).

In his exploration of authenticity, Cohen also addressed Graburn's proposition that tourism is "a sacred journey," a pilgrimage in which tourists move from the profane, compulsory round of work and day-to-day existence to the sacred, unfamiliar, voluntary world of "elsewhere," in which those who escape briefly are refreshed and renewed in specifically "ritualized breaks in routine that define and relieve the ordinary" (Cohen 1977 [1989], 1983a, 1985b). In other words, in the conceptualisations of MacCannell and Graburn, travel for leisure and enjoyment in the encounter with the "other" are translated into journeys of self-discovery, searching for fulfilment and social status.

Cohen, however, argued convincingly for a much more diverse set of motivations and purposes for tourists, and for a concept of authenticity of which the criteria vary depending on the views, perceptions and evaluations of the tourist, always, of course, within the context of the complexities and "unknowables" with which they are faced (Cohen 1988a: 378; and see Kontogeorgopoulos 2003). Authenticity is therefore negotiable and fluid so that "a cultural product, or trait thereof, which is at one point generally judged as contrived or inauthentic may, in the course of time, become generally recognized as authentic" (Cohen 1988a: 379, 2010e). Authenticity, like culture and ethnicity, is also a focus of debate and contestation among local hosts, and 
as Erb suggests, this arises partly from different readings of what authenticity might mean (Cohen 2003: 131-132; and see Allerton 2003: 124-126).

More recent debates on the concept of authenticity and the differences of interpretation between "objectivists," "constructivists" and "post-modernists" have not, in my view, advanced our understanding significantly. However, there appears to be a more general agreement that we should abandon attempts to determine "objective [object] authenticity" and address the diverse and intra- and inter-personal nature of tourist experiences connected to "existential authenticity" (Reisinger and Steiner 2006; Wang Ning 1999). Therefore, we do not abandon the concept of authenticity, rather, we address its socially constructed nature, recognising that tourists can perceive authenticity to their satisfaction even when it is staged. This relational perspective must also embrace tour guides, who articulate and mediate the contested images of tourist sites, and decide whether they present something which they themselves perceive as culturally authentic or as something which responds to market-demands (Dahles 2001: 3).

Cohen constructed a scheme in relation to tourist motivations and authenticity, arguing for a range of tourist types, from "authenticity-seekers" to "recreational" tourists seeking not the authentic but the pleasurable, and to "diversionary" tourists "who seek mere diversion and oblivion... unconcerned with the problem of authenticity of their experiences" (Cohen 1988a: 377; 1979c). In other words, for Cohen, "not all tourists seem to seek authenticity, or to pursue it to the same degree of intensity." Recreational tourists, for example, tend to "exhibit a rather playful attitude to the authenticity of the visited attractions" and they "willingly... cooperate in the game of touristic make-believe" (Cohen 1989a: 32). This "make-believe" was dissected by Cohen when he examined the promotional literature provided by tour guides and agencies on hill tribe trekking tourism in northern Thailand. His assessment of the increasing "gap" between "image" and "reality" provides a poignant reminder of what "staging" entails in the incorporation and display of ethnic minorities (1989a: 30-61, 1992a).

In Cohen's later work with Scott Cohen he takes a rather different direction, and rather than examining personalised tourist experiences and pursuing Wang Ning's tripartite categorisation of objective/object, constructed and existential authenticity (Wang 1999), the Cohens turn their attention to the sources and processes of authentication and who authorises authenticity (Cohen and Cohen 2012a). They discern two kinds of authentication, with reference to Selwyn (1996), though these are not clearly distinguishable categories: the "cool" which refers to accepted, official, authorised definitions 
of authenticity where the authorising agent is usually identified; and the "hot" which addresses the arena of authenticity construction comprising "perpetual transformation," "augmentation" and "(re)enactment." "Hot" authentication involves the "immanent, reiterative, informal performative process of creating, preserving and reinforcing an object's, site's or event's authenticity"; the authorising process is much more problematical to identify (Cohen and Cohen 2012a: 1300, 1310-1311). This seems to me to be a positive way forward in handling the increasingly problematical analytical status of the concept of authenticity.

\section{Tourism, Globalisation and Commoditisation}

In much of Cohen's work on Thailand there is an underlying theme which addresses the provision or production of tourist experiences and resources as consumables or commodities to be displayed, sold and appropriated (see Selwyn 1993: 119-120; Urry 1995; Watson and Kopachevsky 1994). These considerations must be placed in a post-modern, globalised context within which culture and society become increasingly fragmented, pluralised, contested, imagined and commoditised and "distinctions between 'real' versus 'fake' and 'natural' versus 'unnatural' [are pushed] beyond recognition" (Burns 1999: 62; Sofield 2000: 49-50; Sofield 2001: 106-108; Urry 1990: 85, 156; Wood 1993: 64-66). Debates about the nature of culture and identity and about whether these are, or elements of them are "authentic" are therefore "complicated by the abrasive power of globalisation, which is strong, visible and increasingly pervasive, especially with the rapid advancement in satellitebased information technology and mass media, together with the invasive dominance of multinational corporations" (Yamashita et al. 1997: 30; see Sofield 2001: 103-120). Culture then is "hybridised" and "deterritorialised" and one finds in, for example, items of material culture and "tourist arts" the embodiment of a range of meanings which defy simple categorisation as genuine handicrafts or "airport art" (Yamashita 2003: 5; Adams 2009).

One of Cohen's major conclusions in his work on northern Thailand is that there are considerable variations in the effects of tourism on local communities and the kinds of tourism activity (2001h [1979c]: 118-120; see Sofield 2001: 104). This, in turn, entails the recognition that tourism is a dynamic, unbounded and variegated phenomenon which is not amenable to one-dimensional explanations, single theory frameworks or "universal generalisations" (Cohen 1979b, 1979c, 2004c; Sofield 2000: 45, 49; Wood 1993: 55). As Wilson warned some time ago: "We must be wary of allowing ourselves to become entrapped by any one conceptual framework" 
(Wilson 1993: 35), a guiding principle which Cohen has adopted in much of his work. Therefore, one way out of this dilemma is precisely Cohen's approach in undertaking wide-ranging comparative studies and selecting appropriate concepts to address the specific research problem in hand. Tourists also differ on a continuum of dependency or degree of institutionalisation, expressed most prominently in Cohen's early quadripartite classification of the institutionalised "organised mass tourists," the less dependent "individual mass tourists," the relatively independent "explorers" and the free-wheeling, discomfort- and novelty-seeking "drifters" (1974: 527-555). But even Cohen's classification did not capture the complexity of the category "tourist;" it was followed by categorisations based on finer discriminations and on different domains of tourism (Smith 1989 [1977]; Smith 1989: 4-6; Wood 1980, 1984; see King 2017). Nevertheless, these attempts at classification, while necessary, have tended to lead to stereotyping and over-simplification, and by their nature have underplayed the dynamics of tourism as a process.

Tourism as well as embodying and expressing a process of differentiation is also intertwined in other processes of modernisation. This poses one of the greatest challenges to tourism research in that it is often difficult to disentangle the "impacts" of tourism development in a rapidly developing country like Thailand from other processes of change, particularly with the rapid expansion of the international media and electronic communication. In the case of island communities and small scale tribal populations or minorities directly exposed to tourism activities (see Cohen 2001a, 2001e, 2001g), the exercise to identify sources of change might be straightforward, but even these transformations are unlikely to be only tourism-generated. As Cohen said, in his study of hill tribe tourism, it is a "difficult task... isolating the impact of tourism from other kinds of impacts on the tribal communities emanating from the wider society" (2001h [1979c]: 117). Nevertheless, overall, "The growth of tourism in Thailand did not occur in isolation-as it did in some small, isolated island states on which tourism is the principal or sole industry; rather, tourism grew hand in hand with the rapid economic development of the country, comprising the industrial, financial, communicative, and service sectors" (Cohen 2001a: 24; Elliott 1983).

His overall assessment in the mid-1990s, using the notion of "impact," rather than "touristification" was that the effect of tourism on "mainstream Thai culture has had some creative as well as debasing consequences." However, the impact "on the way of life of some small and vulnerable ethnic groups... can be seriously detrimental" (Cohen 2001a: 26-27; Dearden 1996; Dearden and Harron 1994; Toyota 1996). It seems that the concept of "touristification" 
is not so appropriate for Thailand; tourism in Bangkok, for example, given that it has developed in a highly cosmopolitan, urban environment, has not "touristified" Thai culture. It is one of many forces of change. The effects of tourism are more dispersed and disparate in a much more segmented industry than in a "touristified" site like Bali; Thailand's tourism has not concentrated on specific ethnic groups nor has there been a focus on cultural diversity within an overall national culture. Cohen has fully recognised processes of staging and cultural invention, but he has tended to view "impacts" and the commercialisation of culture and nature as having both negative and positive effects.

\section{An Emerging Mobilities Paradigm and Alternatives?}

More recently Erik Cohen, in an extraordinarily productive partnership with Scott Cohen, has drawn attention to the context within which tourism and emerging forms of tourism are developing in a globalising world. The main concerns in these processes are the increasing pace of change; time-space compression; our saturation in information and images generated through the global media; the fragmentation of social and cultural life; increasing risk and insecurity; pervasive consumerism and commoditisation; and cultural pluralisation (Cohen and Cohen 2012a, 2012b). What are the concepts which have emerged to address these changes? The dominant concepts in the study of tourism have been provided through sociological-anthropological research and through political economy and historical perspectives. However, a constant theme running through much of this endeavour was the need to understand the interactions and relationships - the "encounters"-between a range of stakeholders and interest groups engaged in tourism. Cohen, in eschewing a general theoretical framework, in his second collection of essays, instead set out a range of issues or guiding principles for research; some of these relate to notions of globalisation and the combination of the insights from sociology and anthropology. He points to the importance of comparative research, and the linkages and "linking institutions" between tourism activities and the wider socio-cultural and political context; the sources and dynamics of "tourismrelated events and processes"; the tensions and conflicts, and the power relations between local residents and small-scale businesses on the one hand and outsiders and large-scale business on the other; the agency exercised by local populations; the conflicts between commercialisation, and local cultural and environmental preservation and autonomy; and the "incongruities" between values and beliefs and between these and the circumstances on the 
ground, and how these are mitigated, resolved or deployed to enhance the attraction of touristic assets. Importantly, he also emphasises the increasing profile of domestic and Asian tourism, which may require tourism research to rethink some of the concepts based on Western perspectives and interests, and find ways of developing approaches to address emerging touristic phenomena (Cohen 2008a: 15-21). So, what is the way forward?

\section{Mobilities}

Erik Cohen and Scott Cohen have been developing a conceptually sophisticated attempt to overcome the perceived problem of Eurocentrism or Westerncentred perspectives. This critical intervention refers to Syed Farid Alatas's call for "alternative discourses" (Alatas 1993, 2001, 2003, 2004, 2005, 2006, 2015) and Syed Hussein Alatas's critical stance on "intellectual imperialism" and Western "Orientalism" (Alatas 1956, 1974, 1977, 1979, 2000). The Cohens have proposed that a "mobilities" approach to "discretionary travel" might serve to address the Eurocentric character of conceptual frameworks in the sociology of tourism (2012a, 2015a, 2015b, 2015c). More than this they argue that a mobilities perspective might also serve to set in motion a "paradigmatic shift" in the sociology-anthropology of tourism. Their work has emerged in the context of globalised processes of change and the expansion and differentiation of the experience, contexts and consequences of personal mobility.

For me the value of the approach of the Cohens is to address the issue of the problematical nature of tourism (and tourism studies) as a category and as a unified and defined field of study. They draw attention to the fact that there is now a range of phenomena, events and activities which are included (or becoming increasingly so) within tourism, but which were previously considered within other forms of scholarly enquiry or seen as part of other arenas of social, cultural, economic and political life, and encapsulated within a process of physical movement: international and domestic business, labour mobility, trans-national migration, diasporas, retirement abroad. In this regard, they are often referred to as "new or emergent tourisms" or, like ecotourism, "alternative" or "sustainable" forms of tourism. In addition, the mobilities approach throws up other motivations for travel, not necessarily to seek authenticity or an escape from the regularity of every-day life, but rather to pursue prestige and markers of modernity. There is no longer a clearcut division (if there ever was) between the ordinary and extraordinary and between work and leisure (Cohen and Cohen 2012b: 2181-2183). 
Well before the Cohens drew attention to the possibilities of a mobilities approach in tourism research, Franklin and Crang had argued for the relocation of the study of tourism within a broader conceptual field; they had perceived tourism as "no longer a specialist consumer product or mode of consumption," nor a definitive and exotic event, process or phenomenon of minor or marginally eccentric importance in post-modern life, but instead "a significant modality" which was contributing to the organisation and transformation of people's every-day lives (Franklin and Crang 2001: 6-7; and see Rojek 1995; Rojek and Urry 1997; Inglis 2000). In other words, "more or less everyone now lives in a world rendered or reconfigured as interesting, entertaining and attractive-for tourists" (Franklin and Crang 2001: 9).

The Cohens take their inspiration from the pioneer voice in the sociology of mobilities, the late John Urry (Urry 2000, 2007). Urry has been concerned, in association with Kevin Hannam and Mimi Sheller among others, to develop our understanding in a higher level conceptual way of the processes, character and consequences of movement (Hannam and Knox 2010; Hannam et al. 2006: 1-22; Sheller and Urry 2004, 2006: 207-226). But, as Sheller indicates, citing Urry, the concept of "mobilities" does not (as yet) comprise a coherent conceptual model, but rather captures the coming together of disparate fields of study (Sheller 2011: 3; Urry 2007). It therefore does not, in my view, constitute a paradigm, though it marks an important watershed in Erik Cohen's (and Scott Cohen's) perspectives (Harrison 2017). Prior to his engagement with "mobilities," it seems to me Erik Cohen eschewed attempts at developing larger-scale or all-embracing paradigms. He invariably operated at a lower conceptual or middle-range level.

In their earlier excursions into what they have styled the developing paradigm of mobilities, the Cohens also explored two other interrelated "novel theoretical approaches." These comprise: the performativity approach and actor-network theory (Cohen and Cohen 2012b: 2180-2186). They suggest that the "mobilities" paradigm and these other approaches are not yet fully formed, but they do appear to offer exciting ways forward in understanding travel. In my view, though "mobilities" is styled "a paradigmatic shift" (and see Harrison's critical view of the paradigmatic claims for a mobilities approach, 2017), it does not encompass, nor can it address analytically the total field of touristic encounters; this appears to be the reason why the Cohens elaborate other perspectives designed to address the issue of interactions between a range of actors and interest groups.

The mobilities paradigm applied to tourism studies has been critically examined by several authors, raising issues to do with the conceptualisation of 
"discretionary" as against "compulsory" or "necessary" travel in, for example, business travel; the politico-economic or "power" context of the regulation of mobility, and the "frictions" or "blockages" on travel (see, for example, Chen and Chang 2015; Coles 2015; Rogerson 2015; and see Hall 2015; and responded to by Erik and Scott Cohen 2015b: 68-69).

\section{Performativity}

I have already argued elsewhere (King 2015a: 512-513) that the notion of "performativity" is not as "novel" as the Cohens suggest (Cohen and Cohen 2012b: 2183-2184); it is a loose concept embracing expressions and actions which include well-established sociological concepts (behaviour and meaningful bodily movement, identity, symbolic and self-representation, impression management, staging, imaging and simulation). But what the Cohens draw attention to are the ways in which performance is connected to the creation of places and identities (both for residents and those visiting) and to the structuring and changing of relationships and meanings through an increasingly "reflexive awareness" in tourist sites (Edensor 2001, 2007; Franklin and Crang 2001: 10). In other words, "performativity" does not only refer to the staging of tourist-related events, but also to tourist behaviour and reflections (Bruner 2005). It also comprises the translation of symbolic categories and representations into concrete, observable acts which often form part of a repetitive cultural repertoire presented to and in interaction with tourists, but which can be subject to modification and change depending on consumer demands and the reflections and perceptions of those involved in the staging of their culture. The concept of "performativity" also resonates with earlier concerns in tourism studies, exemplified in Selwyn's study of symbolism, images, myths, representations and semiotics (Selwyn 1996). However, "performativity" does not have the status of a paradigm (established or emerging). Much of what is included in this framework can be accommodated within the sociological-anthropological concept of "encounter."

\section{Actor-Network Theory}

Again, the notion of "actor-network theory" (Cohen and Cohen 2012b: 21842186) does not provide anything that is especially original; any analysis of tourist experiences has to examine relations and networks between people/ actors/mediators/translators and between humans and the non-human (things/ objects/communicative devices); in this regard, according to the Cohens, networks are seen as project-specific, in flux, hybrid and heterogeneous 
(Van der Duim 2007). The emphasis is on impermanence, but networks can also be sustained and given substance by continuous performance and reenergising; in other words, there can be a degree of consolidation so that some relationships become more solid and on-going than others, and regularities and patterns are discernible (Boissevain 1979: 392-394; Boissevain and Mitchell 1973). Furthermore, the dynamism and transformative capacities in networks are not only located in "translators" or "mediators." Again, the concept of "encounter" can address the problems generated by this element of the Cohens' approach.

\section{Encounters}

A persistent theme in research on tourism in Southeast Asia during the past three decades has been the importance of understanding encounters and interactions, drawing in part on symbolic interactionist perspectives (Berg 2001: 8-10; Blumer 1969: 5; Goffman 1959), and situated within an understanding of wider processes and structures of change and in relation to issues of culture and identity (King 2015a, 2015b, 2016b). The concern with encounters was captured in Smith's dual categorisation of "hosts and guests" and their interrelationships (Smith 1989 [1977], 1989); it has remained central to my recent work on heritage sites, though this simple categorical opposition between local residents and guests needs considerable elaboration to address the complexities of touristic encounters and the domestic and intra-Asian dimension (King 2016b; Sherlock 2001; Smith 1989).

I have argued elsewhere that our understanding of encounters, including both chance and planned or arranged engagements and those which are one-off or multiple, regular or irregular, reciprocal, collaborative, complementary or adversarial is still the central focus of the tourist experience. These encounters comprise person-to-person relationships, those between groups (or at least between members or representatives of groups), and those between local communities and national and international bodies and agencies. They also embrace interactions of individuals and groups within electronic and media networks and with information technology (which includes images and representations), between individuals and information provided in material form (guidebooks, tourist and government agency literature, travel books, signage and displays at sites), and between individuals and material objects (in museums, exhibition centres, at archaeological and heritage sites, and in natural landscapes). Encounters between people are often cross-ethnic, crosscultural and cross-national; but with the rapid increase in travel and tourism 
within national boundaries, and between similar culture areas, the crosscultural dimension needs qualification. This in turn poses questions about the distinction and sometimes opposition between domestic and international tourists, though this categorisation remains a useful way to capture broad differentiations. Encounters also encompass the behaviours generated (in bodily expressions, language, dress), the motivations and interpretations implicated in them, and their character (for example whether they are one-off and temporary, or continuous, reciprocal or conflictual). This concept embraces the Cohens' concepts of "performativity" and "actor-network theory." However, I stress that the concept of "encounter" is a low level conceptual framework; it is not part of a theoretical scheme or paradigm.

\section{CONCLUDING REMARKS}

It is an almost impossible task to provide a detailed evaluation of Erik Cohen's prolific publication record, extending over a period of more than 40 years and covering such a broad range of ethnographic subjects and concepts (see, for example, Cohen 2001c, 2004c, 2008a, 2014c). All I have been able to do is present some significant themes, ideas and findings. It would take a substantial critical volume to do justice to his innovative and pioneering research career. I have had the pleasure of engaging Erik Cohen in conversation in Chiang Mai on several occasions and exchanging numerous emails with him. When I mentioned that I was preparing a critical appreciation of his work, he responded generously and modestly, with reflections on his work on Thailand. I think it captures what Scott Cohen has referred to as Erik Cohen's rather "serendipitous," "gradual," "opportunistic" and "eclectic" scholarly engagement with tourism (Scott Cohen 2013). It suggests that a higher level theoretical approach is not part of Erik Cohen's repertoire (see Cohen 2004c); indeed, given his very broad ethnographic reach, it is difficult to envisage what theoretical approach might encompass it. His response to me, in an email (pers. comm. 2 May 2017) captures precisely his contribution to research on Thai tourism, which he characterises as "a piecemeal approach." He says, "I have never quite linked the dynamics of tourism with the broader political and social developments in the country; nor is my work on the micro or mezzoscale fully integrated with the macro-theoretical work, either that of the 197080 s or (in the work with Scott [Cohen]) of the 2010s."

Therefore, Erik Cohen has not been inclined to construct a grand theoretical scheme, although he has argued cogently with Scott Cohen, on 
behalf of the possible paradigmatic status of "mobilities" (Cohen and Cohen 2012b). But has he? Paradoxically, he seems to have moved gradually to a higher-level theory in pursuing what is clearly a productive conceptual framework of "mobilities," but then, in my view, he has hesitated and offered additional concepts (not paradigms?) of "performativity" and "actor-network theory." Although he also qualifies his binaries in post-modern terms, he proposes with Scott Cohen, a future for research on tourism (Cohen and Cohen 2012b), with which I would not take issue, and I hope that the purpose of this paper is to promote and endorse this agenda. But while I welcome "mobilities" as a contextualisation of what we are currently doing and hope to achieve in tourism research, my inclination is to engage much more decisively with "performativity" and "actor-networks," embraced within the concept of "encounters." In another email to me (pers. comm. 11 June 2017), Erik Cohen has remarked that I have misunderstood his intentions in relation to "mobilities," in that this was not "a theoretical construction on our part" but merely "an invited review of the state of the art" (a position reinforced by Scott Cohen in a recent email to me, pers. comm. 3 January 2018). This is for me a confirmation of his approach to theory; like me he is content with a lower level conceptualisation (King 2009). But I still sense, in his work with Scott Cohen, a desire to try to move tourism studies into a new paradigmatic arena. This is certainly Harrison's interpretation of the Cohens' work as well (2017).

Having moved beyond such concepts as "authenticity" and "the tourist gaze," Erik and Scott Cohen present us with a movement from "synchronic" to "diachronic" perspectives, from "permanence" to "flux," from "being" to "doing," from "structure" to "agency," from "sedimented social patterns" to the "process of their emergence" and ultimately from "stable fixtures" of social and cultural life to "mobilities." For me the only remaining question is whether "mobilities" constitutes a paradigm? Ultimately it does not matter all that much to me in that Erik Cohen's contribution to our ethnographic knowledge, understanding and contemplation of tourism in Thailand will stand the test of time. He has moved from the social-structural to the symbolic, from the organisational to the post-modern. What impresses me is that he has regularly and constantly anticipated future developments in tourism research; he has a prescient presence; not only that but, being resident in Thailand over many years, he has served almost as a roving scholarly reporter of tourism developments in Thailand: from disasters to floating markets; from festivals to animals; from pilgrimage to prostitution; from the commodification of crafts to spirit mediumship; from tattoos to food. 
And I need to rectify a comment that I made some years ago about Erik Cohen's Thai-centric approach. His critical and thoughtful commentaries on the development of tourism in Thailand are exemplary. They are unsurpassed; I cannot recall a corpus of research on any other part of the world that captures and understands what is happening to a country which has engaged in tourism development during the past 40 years. Furthermore, his work on ethnicity and tourism in Southeast Asia generally and mainland Southeast Asia specifically and his more general pronouncements about tourism research in Southeast Asia (Cohen 1999) proves me wrong about his Thai-centrism (Cohen 2001i, 2008c, 2016c). My current assessment is that he has captured, explained and helped us understand what tourism means to us, how we experience it, its significance in a globalising world, and the consequences of our increasing involvement in travel and leisure; this is no small accomplishment. In emails (pers. comm. 11 June 2017; 6 January 2018) from him, with due modesty, he suggests that "I exaggerate the significance of [his] work" and the paper "seems too laudatory." I disagree. 
Author's note: Following are images taken by the author in Chiang Mai in 2014, 2015 and 2016 when he met Professor Cohen (Figure 1) at tourism studies conferences organised by Chiang Mai University, Thailand. Chiang Mai, a major tourist centre in northern Thailand, and the neighbouring religious and tourist site of Wat Phra That Doi Suthep was visited by Erik Cohen for two weeks in 1973; it marked a turning point in his research career when he subsequently embarked on his studies of "hill tribe tourism." The subsequent images are of tourists and sites in Chiang Mai: the Three Kings Monument in central Chiang Mai; the reservoir at Chiang Mai University visited by Chinese tourists; and the temple complex of Doi Suthep with the statue of Phra Kuba Srivichai.

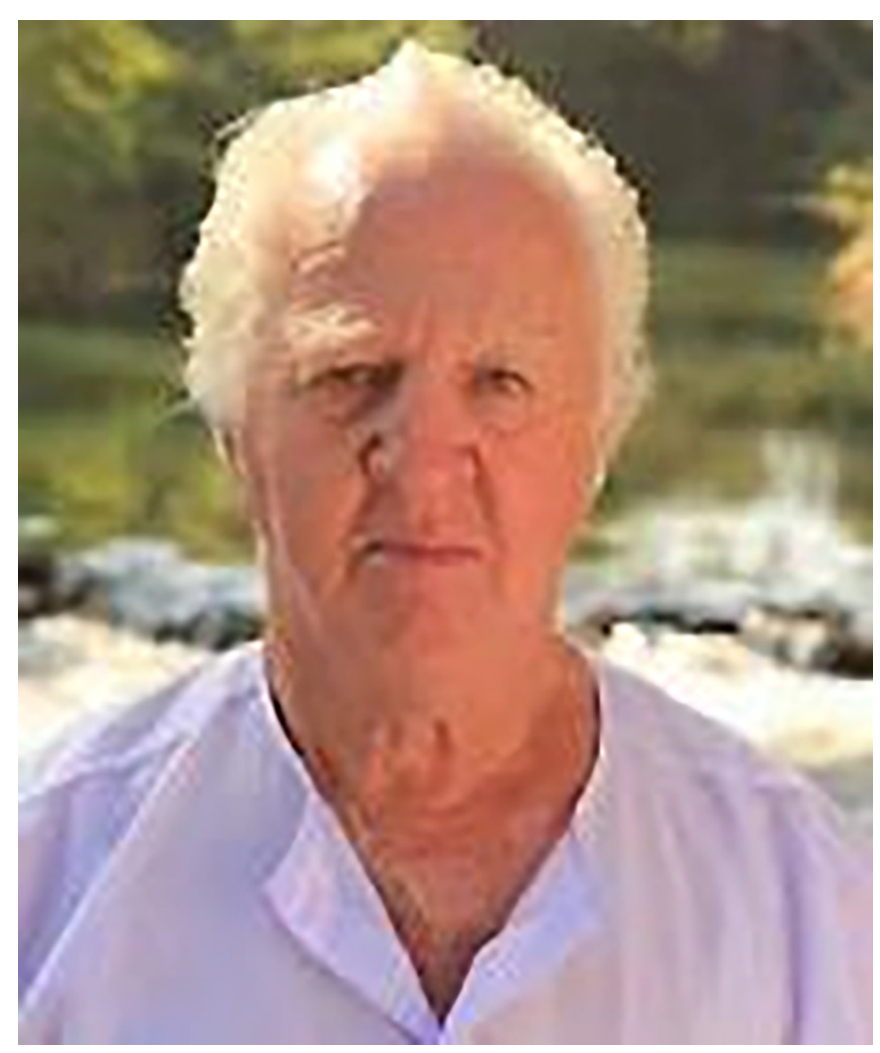

Figure 1: Photo of Eric Cohen. 


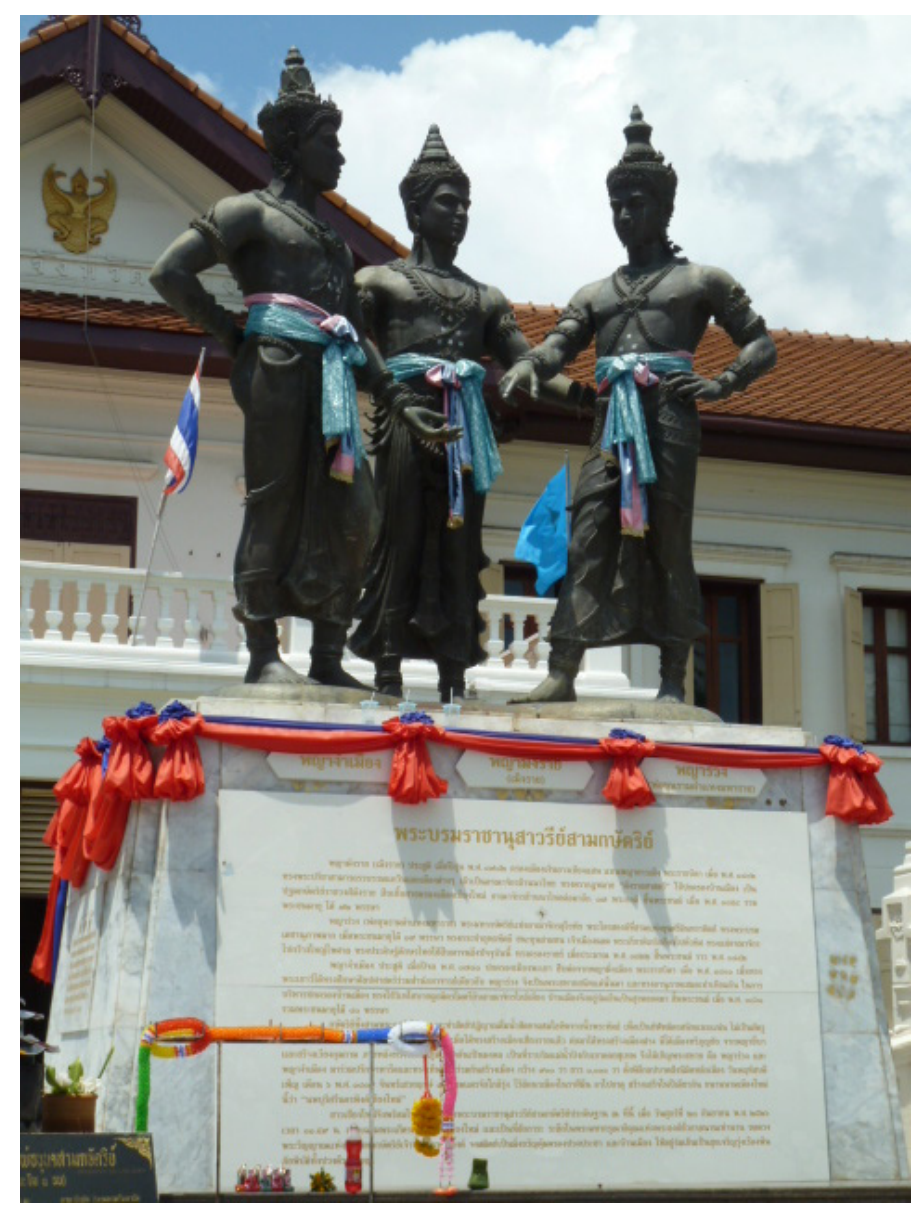

Figure 2: Three Kings Monument in central Chiang Mai.

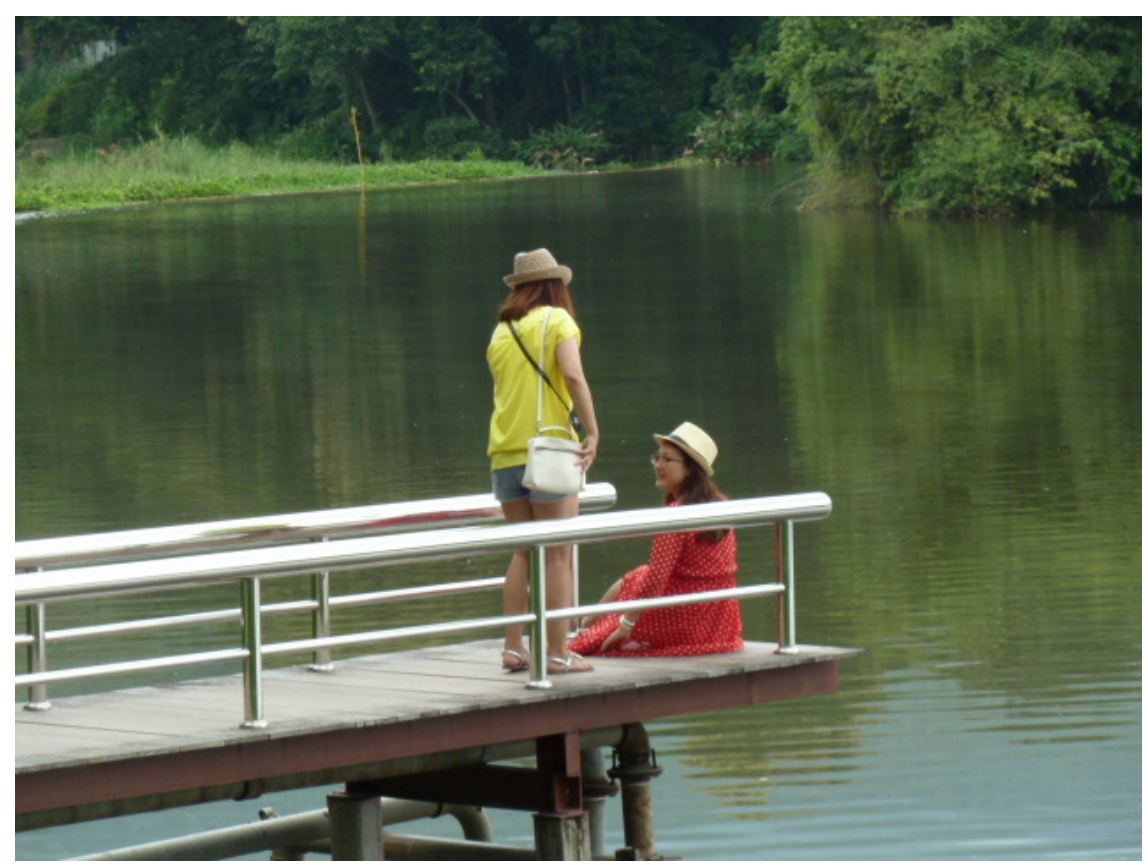

Figure 3: Reservoir at Chiang Mai University visited by Chinese tourists. 


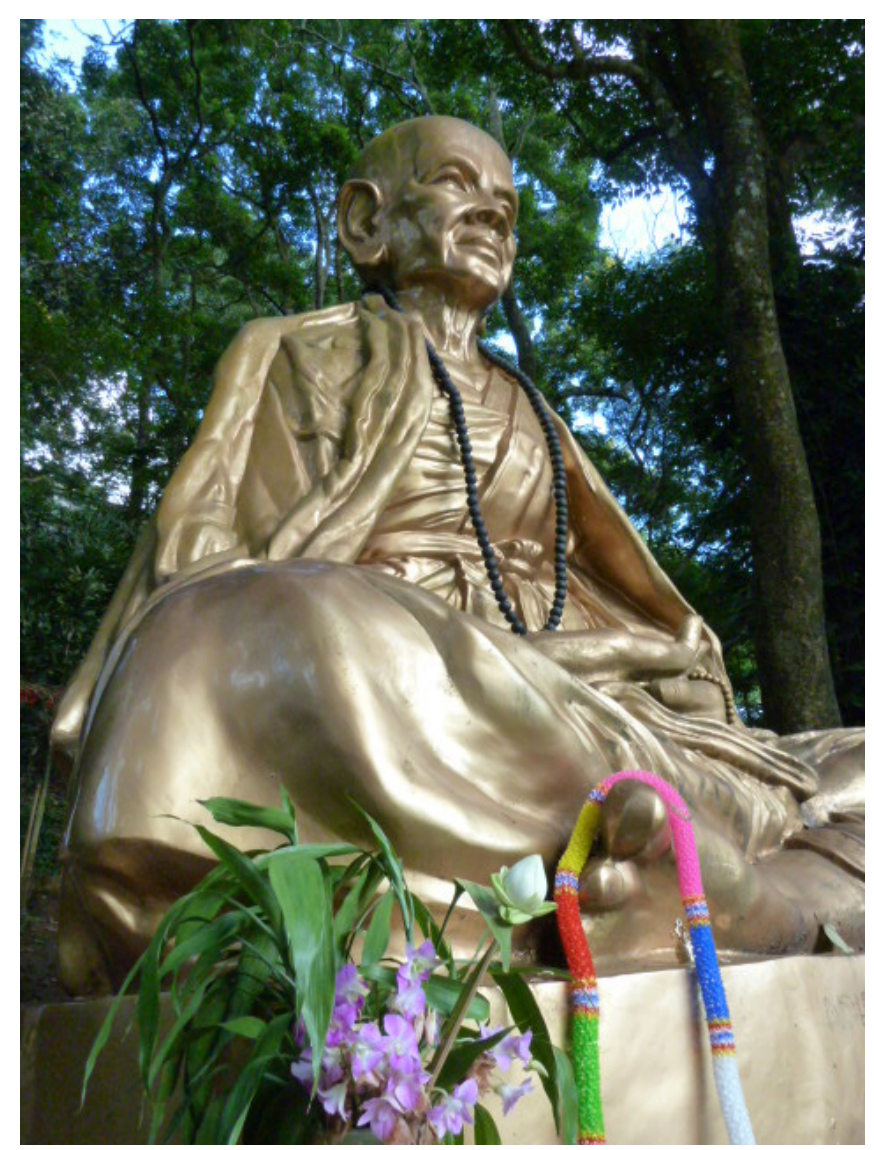

Figure 4: Temple complex of Doi Suthep with the statue of Phra Kuba Srivichai.

\section{NOTES}

* Victor T. King is Professor of Borneo Studies, Institute of Asian Studies, Universiti Brunei Darussalam; Emeritus Professor at the University of Leeds, United Kingdom; Professorial Research Associate, School of Oriental and African Studies (University of London), United Kingdom; and Occasional Visiting Professor, Chiang Mai University, Thailand. He has long-standing interests in the sociology and anthropology of Southeast Asia, ranging over such fields as social and cultural change, development, tourism and heritage, ethnicity and identity, multidisciplinary regional studies, and museum and photographic studies. Among his recent publications are an edited book, UNESCO in Southeast Asia: World Heritage Sites in Comparative Perspective (2016, NIAS Press), and co-edited books on Tourism and Monarchy in Southeast Asia (2016, Cambridge Scholars Publishing), Tourism and Ethnodevelopment: Inclusion, Empowerment and Self-determination (2018, Routledge) and Tourism in East and Southeast Asia (2018, Routledge).

** This paper is a revised version of a presentation delivered at the 13th International Conference on Thai Studies, 15-18 July 2017, organised and supported by Chiang Mai University, Thailand. 


\section{REFERENCES}

Adams, K. 2009. Indonesian souvenirs as micro-monuments to globalization and modernity: Hybridization, deterritorialization and commodification. In Tourism in Southeast Asia: Challenges and new directions, eds. Hitchcock, M., King, V. T. and Parnwell, M., 69-82. Copenhagen: NIAS Press and Honolulu: University of Hawai'i Press.

Alatas, S. F. 1993. On the indigenization of academic discourse. Alternatives: Global, local, political 18 (3): 307-338, https://doi.org/10.1177/030437549301800303.

2001. Alternative discourses in Southeast Asia. SARI: Jurnal Alam dan Tamadun Melayu 19: 49-67.

2003. Academic dependency and the global division of labour in the social sciences. Current Sociology 51 (6): 599-613, https://doi.org/10.1177/00113921030516003. 2004. The meaning of alternative discourses: Illustrations from Southeast Asia. In Asia in Europe, Europe in Asia, eds. Ravi, S., Rutten, M. and Goh, B. L., 57-78. Amsterdam: IIAS and Singapore: ISEAS Publications.

2005. Afterword. Indigenization: Features and problems. In Asian anthropology, eds. Ben-Ari, E., van Bremen, J. and Alatas, S. F., 227-243. London: Routledge. 2006. Alternative discourses in Asian social sciences: Responses to Eurocentrism. New Delhi: SAGE.

2015. Doing sociology in Southeast Asia. Cultural Dynamics 27: 191-202, https:// doi.org/10.1177/0921374015585227.

Alatas, S. H. 1956. Some fundamental problems of colonialism. Eastern World, November: 9-10.

1974. The captive mind and creative development. International Social Science Journal 34 (1): 9-25.

1977. The myth of the lazy native: A study of the image of the Malays, Filipinos and Javanese from the 16th to the 20th century and its function in the ideology of colonial capitalism. London: Frank Cass.

1979. Toward an Asian social science tradition. New Quest 17: 265-269.

2000. Intellectual imperialism: Definition, traits and problems. Southeast Asian Journal of Social Science 28 (1): 23-45, https://doi.org/10.1163/030382400X00154.

Allerton, C. 2003. Authentic housing, authentic culture? Transforming a village into a "tourist site" in Manggarai, Eastern Indonesia. Indonesia and the Malay World 31 (89): 119-128, special issue on Tourism and Heritage in South-East Asia, eds. Hitchcock, M. and King, V. T.

Berg, B. L. 2001. Qualitative methods for the social sciences. Massachusetts: Allyn and Bacon.

Blumer, H. 1969. Symbolic interactionism: Perspective and method. New Jersey: PrenticeHall.

Boissevain, J. 1979. Network analysis: A reappraisal. Current Anthropology 20 (2): 392394, https://doi.org/10.1086/202277.

Boissevain, J. and Clyde Mitchell, J. eds. 1973. Network analysis: Studies in human interaction. The Hague: Mouton Publishers.

Bruner, E. M. 2005. Culture on tour: Ethnographies of travel. Chicago: Chicago University Press.

Burns, P. M. 1999. An introduction to tourism and anthropology. London: Routledge. 
Chen, J. and Chang, T. C. 2015. Mobilising tourism research in emerging world regions: Contributions and advances. Current Issues in Tourism 18 (1): 57-61, https://doi.or g/10.1080/13683500.2014.932337.

Cohen, E. 1972. Toward a sociology of international tourism. Social Research 39 (1): 164 182.

1974. Who is a tourist? A conceptual clarification. Sociological Review 22 (4): 527-555, https://doi.org/10.1111/j.1467-954X.1974.tb00507.x.

1978. The impact of tourism on the physical environment. Annals of Tourism Research 5 (2): 215-237, https://doi.org/10.1016/0160-7383(78)90221-9.

1979a. A phenomenology of tourist experiences. Sociology 13 (2): 179-201, https://doi.org/10.1177/003803857901300203.

1979b. Rethinking the sociology of tourism. Annals of Tourism Research 6 (1): 18-35, https://doi.org/10.1016/0160-7383(79)90092-6.

(ed.). 1979c. Sociology of tourism. Annals of Tourism Research 6 (1-2): 17-194. 1982a. Jungle guides in Northern Thailand: The dynamics of a marginal occupational role. Sociological Review 30 (2): 234-266, https://doi.org/10.1111/ j.1467-954X.1982.tb00756.x.

1982b. Thai girls and Farang men: The edge of ambiguity. Annals of Tourism Research 9 (3): 403-428, https://doi.org/10.1016/0160-7383(82)90021-4.

1982c. Marginal paradises: Bungalow tourism on the islands of Southern Thailand. Annals of Tourism Research 9 (3): 189-228.

1983a. The dynamics of commercialized arts: The Meo and Yao of Northern Thailand. Journal of the National Research Council of Thailand 15 (1), Part II: $1-34$.

1983b. Insiders and outsiders: The dynamics of development of bungalow tourism on the islands of Southern Thailand. Human Organization 42 (2): 158-162, https://doi.org/10.17730/humo.42.2.45767335470438t0.

1983c. Hill tribe tourism. In Highlanders of Thailand, eds. McKinnon, J. and Bhruksasri, W., 307-325. Kuala Lumpur: Oxford University Press.

1984a. The sociology of tourism: Approaches, issues and findings. Annual Review of Sociology 10: 373-392, https://doi.org/10.1146/annurev.so.10.080184.002105. 1984b. The dropout expatriates: A study of marginal Farangs in Bangkok. Urban Anthropology 13 (1): 91-114.

1985a. The tourist guide: The origins, structure and dynamics of a role. Annals of Tourism Research 12 (1): 5-29, https://doi.org/10.1016/0160-7383(85)90037-4. 1985b. Tourism as play. Religion 15 (3): 291-304, https://doi.org/10.1016/0048$721 \mathrm{X}(85) 90016-8$.

1986. Lovelorn Farangs: The correspondence between foreign men and Thai girls. Anthropological Quarterly 59 (3): 115-127, https://doi.org/10.2307/3317198.

1987a. Alternative tourism - A critique. Tourism Recreation Research 12 (2): 1318, https://doi.org/10.1080/02508281.1987.11014508.

1987b. Sensuality and venality in Bangkok: The dynamics of cross-cultural mapping of prostitution. Deviant Behavior 8 (3): 223-234, https://doi.org/10.1080/ 01639625.1987 .9967745$.

1988a. Authenticity and commoditization in tourism. Annals of Tourism Research 15 (3): 371-386, https://doi.org/10.1016/0160-7383(88)90028-X. 
1988b. From tribal costume to pop fashion: The "bouquitisation" of the textiles of the hill tribes of Northern Thailand. Studies in Popular Culture 11 (2): 49-59.

1988c. Tourism and AIDS in Thailand. Annals of Tourism Research 15 (4): 467486, https://doi.org/10.1016/0160-7383(88)90044-8.

1988d. Traditions in the qualitative sociology of Tourism. Annals of Tourism Research 15 (1): 29-46, https://doi.org/10.1016/0160-7383(88)90069-2.

1989a. "Primitive and remote," hill tribe trekking in Thailand. Annals of Tourism Research 16 (1): 30-61.

1989b. The commercialisation of ethnic crafts. In Craft reports from all around the world, 94-103. Copenhagen: World Crafts Council.

1989c. International politics and the transformation of folk crafts - The Hmong

(Meo) of Thailand and Laos. Journal of the Siam Society 77 (1): 69-82.

1992a. The growing gap: Hill tribe image and reality. Pacific Viewpoint 33 (2):

165-169.

1992b. Who are the Chao Khao? "Hill Tribe" postcards from Northern Thailand. International Journal of the Sociology of Language 98: 101-125.

1992c. Pilgrimage centers: Concentric and excentric. Annals of Tourism Research 19 (1): 33-50, https://doi.org/10.1016/0160-7383(92)90105-X.

1993a. The heterogeneization of a tourist art. Annals of Tourism Research 20 (1):

138-163, https://doi.org/10.1016/0160-7383(93)90115-J.

1993b. The study of touristic images of native people: Mitigating the stereotype of a stereotype. In Tourism Research, eds. Pearce, D. G. and Butler, B. W., 36-69, London: Routledge.

1993c. Open-ended prostitution as a skilful game of luck: Opportunity, risk and security among tourist-oriented prostitutes in a Bangkok Soi. In Tourism in SouthEast Asia, eds. Hitchcock, M., King, V. T. and Parnwell, M. J. G., 155-178. London and New York: Routledge.

1995a. Golf in Thailand: From sport to business. Southeast Asian Journal of Social Science 23 (2): 1-17, https://doi.org/10.1163/030382495X00097.

1995b. Contemporary tourism - Trends and challenges: Sustainable authenticity or contrived modernity? In Change in tourism: People, places, processes, ed. Cohen, E., 12-29. London: Routledge.

1996a. Temporal ambiguity in Hmong representational textile art. Visual Anthropology 9 (1): 25-40, https://doi.org/10.1080/08949468.1996.9966689.

1996b. Touting tourists in Thailand: Tourist oriented crime and social structure. In Tourism, crime and international security issues, eds. Abraham, P. and Mansfeld, Y., 77-90, New York: John Wiley.

1997. Tourism-related crime: Towards a sociology of crime and tourism. Visions in Leisure and Business 16 (1): 4-14.

1999. Towards an agenda for tourism research in Southeast Asia. Asia Pacific Journal of Tourism Research 4 (2): 79-89, https://doi.org/10.1080/10941669908722048. 2000. The commercialized crafts of Thailand: Hill tribes and lowland villages. London: Curzon Press and Honolulu: University of Hawai'i Press.

2001a. Thai tourism: Trends and transformations. In Thai tourism: Hill tribes, islands and open-ended prostitution. Collected papers, 2nd ed., ed. Cohen, E., 1-28. Bangkok: White Lotus Press, Studies in Contemporary Thailand No. 4. 
2001b. Preface. In Thai tourism: Hill tribes, islands and open-ended prostitution. Collected papers, 2nd ed., ed. Cohen, E., ix-xii. Bangkok: White Lotus Press, Studies in Contemporary Thailand No. 4.

2001c. Thai tourism: Hill tribes, islands and open-ended prostitution. Collected Papers, 2nd ed. Bangkok: White Lotus Press, Studies in Contemporary Thailand No. 4.

2001d. Thailand in "touristic transition." In Interconnected worlds: Tourism in Southeast Asia, eds. Teo, P., Chang, T. C. and Ho, K. C., 155-175. Oxford: Elsevier Science, Pergamon.

2001e. "Unspoilt and enchanting": Island tourism in Southern Thailand. In Hosts and guests: The anthropology of tourism, 3rd ed., ed. Smith, V. L., 151-178. Philadelphia: University of Pennsylvania Press.

2001f. The Chinese vegetarian festival in Phuket: Religion, ethnicity and tourism on a Southern Thai island. Bangkok: White Lotus.

2001g. "Marginal paradises" revisited: Tourism and environment on Thai island. In Thai tourism: Hill tribes, islands and open-ended prostitution. Collected papers, 2nd ed., ed. Cohen, E., 225-246. Bangkok: White Lotus Press, Studies in Contemporary Thailand No. 4.

2001h [1979c]. The impact of tourism on the hill tribes of Northern Thailand.

In Thai tourism: Hill Tribes, Islands and Open-ended Prostitution. Collected papers, 2nd ed., ed. Cohen, E. 113-144. Bangkok: White Lotus Press, Studies in Contemporary Thailand No. 4.

2001i. Ethnic tourism in Southeast Asia. In Tourism, anthropology and China, eds.

Tan, C. B., Cheung, S. C. H. and Yang, H., 27-52. Bangkok: White Lotus.

2002. Authenticity, equity and sustainability in tourism. Journal of Sustainable Tourism 10 (4): 267-276, https://doi.org/10.1080/09669580208667167.

2003. Transnational marriage in Thailand: The dynamics of extreme heterogamy. In Sex and tourism: Journeys of romance, love and lust, eds. Bauer, T. G. and McKercher, B., 57-81. New York: The Haworth Hospitality Press.

2004a. Backpacking: Diversity and change. In The global nomad: Backpacker travel in theory and practice, eds. Richards, G. and Wilson, J., 43-59. Clevedon: Channel View.

2004b. Pilgrimage and prostitution: Contrasting modes of border tourism in lower South Thailand. Tourism Recreation Research 29 (2): 89-114, https://doi.org/10.10 80/02508281.2004.11081447.

2004c. Contemporary tourism: Diversity and change. Amsterdam and Boston: Elsevier.

2007a. Youth tourists in acre: A disturbance becomes a lifelong occupation. In The study of tourism: Anthropological and sociological beginnings, ed. Nash, D., 50-59. Oxford and Amsterdam: Elsevier, Tourism Social Science Series.

2007b. "Authenticity" in tourism studies: Aprés la lutte. Tourism Recreation Research 32 (2): 75-82, https://doi.org/10.1080/02508281.2007.11081279.

2008a. Explorations in Thai tourism: Collected case studies. Tourism Social Science Series, vol. 11. Bingley, U.K.: Emerald Group Publishing.

2008b. Death of a backpacker: Incidental but not random. Journal of Tourism and Cultural Change 6 (3): 209-226, https://doi.org/10.1080/14766820802647624. 
2008c. Southeast Asian ethnic tourism in a changing world. Asian Anthropology 7 (1): 25-56, https://doi.org/10.1080/1683478X.2008.10552578.

2009a. Spirit possession and tourism at Thai festivals: A comparative study. Tourism Recreation Research 34 (1): 45-54, https://doi.org/10.1080/02508281.20 09.11081574.

2009b. The wild and the humanized: Animals in Thai tourism. Anatolia: An International Journal of Tourism and Hospitality Research 20 (1): 100-118. .2009c. Death in paradise: Tourist fatalities in the tsunami disaster in Thailand. Current Issues in Tourism 12 (2): 183-199, https://doi.org/10.1080/13683500802531141. 2010a. Medical travel - a Critical assessment. Tourism Recreation Research 35 (3): 225-237, https://doi.org/10.1080/02508281.2010.11081639.

2010b. Panda and elephant - Contesting icons in Thai tourism. Journal of Tourism and Cultural Change 8 (3): 154-175, https://doi.org/10.1080/14766825.2010.510 565.

2010c. Confirmation versus contestation of tourism theories in tourist jokes. Tourism Analysis 15 (1): 3-16, https://doi.org/10.3727/108354210X12724734223478.

2010d. Tourism crises: A comparative perspective. International Journal of Tourism Policy 3 (4): 281-296, https://doi.org/10.1504/IJTP.2010.040389.

2010e. Tourism, leisure and authenticity. Tourism Recreation Research 35 (1): 67-73, https://doi.org/10.1080/02508281.2010.11081620. .2012a. Flooded: An auto-ethnography of the 2011 Bangkok flood. ASEAS: Austrian Journal of South-East Asian Studies 5 (2): 316-334.

2012b. The vegetarian festival and the city pillar: The appropriation of a Chinese religious custom for a cult of the Thai civic religion. Journal of Tourism and Cultural Change 10 (1): 1-21, https://doi.org/10.1080/14766825.2011.637631.

2012c. Tiger tourism: From shooting to petting. Tourism Recreation Research 37

(3): 193-204, https://doi.org/10.1080/02508281.2012.11081708.

. 2012d. Globalization, global crises and tourism. Tourism Recreation Research 37

(2): 103-111, https://doi.org/10.1080/02508281.2012.11081695.

2012e. Major trends in contemporary tourism. In The Routledge handbook of tourism research, eds. Hsu, C. H. S. and Gartner, W. H., 310-323. London and New York: Routledge.

2013. Tattoo Tourism in the Contemporary West and in Thailand. In The Routledge Handbook of Cultural Tourism, eds. Smith, M. and Richards, G. 183-189. London and New York: Routledge.

2014a. From Phra Phum to Phra Prom: The cosmisation of the Thai spirit house. In Southeast Asian mobility transitions: Issues and trends in migration and tourism, eds. Husa, K., Trupp, A. and Wohlschlägl, H., 19, 426-444. Vienna: Abhandlungen zur Geographie und Regionalforschung.

2014b. Heritage tourism in Thai urban communities. Tourism, Culture and Communication 14 (1): 1-15.

2014c. Erik Cohen: Selected list of publications, April 2014. https://sociology. huji.ac.il/sites/default/files/sociology/files/cohen_cv.pdf. (accessed 28 May 2017). 2016a. The permutations of Thailand's "floating markets." Asian Journal of Tourism Research 1 (1): 59-98. 
2016b. Contesting narratives: The Koh Tao tourists murders. Asian Anthropology October, https://doi.org/10.1080/1683478X.2016.1204021.

2016c. Ethnic tourism in mainland Southeast Asia: The state of the art. Tourism Recreation Research 41 (3): 232-245, https://doi.org/10.1080/02508281.2016.118 8485.

Cohen, E. and Avieli, N. 2004. Food in tourism: Attraction and impediment. Annals of Tourism Research 31 (4): 755-778, https://doi.org/10.1016/j.annals.2004.02.003.

Cohen, E. and Cohen, S. A. 2012a. Authentication hot and cool. Annals of Tourism Research 39 (3): 1295-1314, https://doi.org/10.1016/j.annals.2012.03.004.

2012b. Current sociological theories and issues in tourism. Annals of Tourism Research 39 (4): 2177-2202, https://doi.org/10.1016/j.annals.2012.07.009. 2015a. A mobilities approach to tourism from emerging world regions. Current Issues in Tourism 18 (1): 11-43, https://doi.org/10.1080/13683500.2014.898617. 2015b. Tourism mobilities from emerging world regions: A response to commentaries. Current Issues in Tourism 18 (1): 68-69, https://doi.org/10.1080/13 683500.2014 .956705 .

2015c. Beyond Eurocentrism in tourism: A paradigm shift to mobilities. Tourism Recreation Research 40 (2): 157-168, https://doi.org/10.1080/02508281.2015.103 9331.

Cohen, E., Cohen, S. A. and King, V. T. 2016. The global permutations of the Western publication regime. Current Issues in Tourism, https://doi.org/10.1080/13683500.2 016.1272556 (accessed 25 May 2017)

Cohen, E. and Neal, M. 2010. Coinciding crises and tourism in contemporary Thailand. Current Issues in Tourism 13 (5): 455-475, https://doi.org/10.1080/13683500.201 0.491898 .

Cohen, S. A. 2013. A portrait of Erik Cohen. Anatolia: An International Journal of Tourism and Hospitality Research 24 (1): 104-111, https://doi.org/10.1080/13032917.2013 .785694 .

Coles, T. 2015. Tourism mobilities: Still a current issue in tourism? Current Issues in Tourism 18 (1): 62-67, https://doi.org/10.1080/13683500.2014.937325.

Crick, M. 1996. Representation of international tourism in the social sciences: Sun, sex, sights, savings, and servility. In The sociology of tourism: Theoretical and empirical investigations, eds. Apostolopoulos, Y., Leivadi, S. and Yianakis, A., 15-50. London and New York: Routledge.

Crystal, E. 1989 [1977]. Tourism in Toraja (Sulawesi, Indonesia). In Hosts and guests: The anthropology of tourism, 3rd ed., ed. Smith, V. L., 139-168. Philadelphia: University of Pennsylvania Press, https://doi.org/10.9783/9780812208016.139.

Dahles, H. 2001. Tourism, heritage and national culture in Java: Dilemmas of a local community. Richmond: Curzon Press.

2009. Romance and sex tourism. In Tourism in Southeast Asia: Challenges and new directions, eds. Hitchcock, M., King, V. T. and Parnwell, M., 222-235. Copenhagen: NIAS Press and Honolulu: University of Hawai'i Press.

Dann, G. and Cohen, E. 1991. Sociology and tourism. Annals of Tourism Research 18 (1): 155-169, https://doi.org/10.1016/0160-7383(91)90045-D. 
Dearden, P. 1996. Trekking in Northern Thailand: Impact distribution and evolution over time. In Uneven development in Thailand, ed. Parnwell, M. J. G., 204-225. Aldershot: Avebury.

Dearden, P. and Harron, S. 1994. Alternative tourism and adaptive change: Insights from Northern Thailand. Annals of Tourism Research 21 (10): 81-102, https://doi. org/10.1016/0160-7383(94)90006-X.

Edensor, T. 2001. Performing tourism, staging tourism. Tourism Studies 1 (1): 59-81, https://doi.org/10.1177/146879760100100104.

2007. Mundane mobilities: Performances and spaces of tourism. Social and Cultural Geography 8 (2): 199-215, https://doi.org/10.1080/14649360701360089.

Elliott, J. 1983. Politics, power, and tourism in Thailand. Annals of Tourism Research 10 (3): 377-393, https://doi.org/10.1016/0160-7383(83)90063-4.

Erb, M. 2000. Understanding tourists: Interpretations from Indonesia. Annals of Tourism Research 27 (3): 709-736, https://doi.org/10.1016/S0160-7383(99)00102-4.

. 2003. Uniting the bodies and cleansing the village: Conflicts over local heritage in a globalizing world. Indonesia and the Malay World 31 (89): 129-139, special issue on Tourism and Heritage in South-East Asia, eds. Hitchcock, M. and King, V. T.

Forsyth, T. J. 1995. Tourism and agricultural development in Thailand. Annals of Tourism Research 22 (4): 877-900 https://doi.org/10.1016/0160-7383(95)00019-3.

Franklin, A. and Crang, M. 2001. Editorial: The trouble with tourism and travel theory. Tourist Studies 1 (1): 5-22, https://doi.org/10.1177/146879760100100101.

Goffman, E. 1959 [1956]. The presentation of self in everyday life. New York: Doubleday Anchor Books.

Graburn, N. H. H. ed. 1976. Ethnic and tourist arts: Cultural expressions from the Fourth World. Berkeley: University of California Press. 1989 [1977]. Tourism: The sacred journey. In Hosts and guests: The anthropology of tourism, 2nd expanded ed., ed. Smith, V. L., 21-36. Philadelphia: University of Pennsylvania Press.

1983. The anthropology of tourism. Annals of Tourism Research 10 (1): 9-33, https://doi.org/10.1016/0160-7383(83)90113-5.

. 2004. Biography of Erik Cohen, Hebrew University, Jerusalem. In Biographical Dictionary of Social and Cultural Anthropology, ed. Amit, V., 94-95. London and New York: Routledge.

Hall, C. M. 2015. On the mobility of tourism mobilities. Current Issues in Tourism 18 (1): 7-10, https://doi.org/10.1080/13683500.2014.971719.

Hall, C. M. and Page, S. eds. 2000. Tourism in South and Southeast Asia: Issues and cases. Oxford: Butterworth Heinemann.

Hannam, K. and Knox, D. 2010. Understanding tourism: A critical introduction. London: Sage.

Hannam, K., Sheller, M. and Urry, J. 2006. Editorial: Mobilities, immobilities, moorings. Mobilities 1 (1): 1-22, https://doi.org/10.1080/17450100500489189.

Harrison, D. 2017. Tourists, mobilities, paradigms. Tourism Management 63: 329-337, https://doi.org/10.1016/j.tourman.2017.07.002.

Hitchcock, M. 1999. Tourism and ethnicity: Situational perspectives. International Journal of Tourism Research 1 (1): 17-32. 
Hitchcock, M. and King, V. T. eds., 2003. Tourism and heritage in South-East Asia. Special issue of Indonesia and the Malay World 31 (89), https://doi.org/10.1002/(SICI)15221970(199901/02)1:1\%3C17::AID-JTR145\%3E3.0.CO;2-L.

Hitchcock, M., King, V. T. and Parnwell, M. J. G. eds. 1993. Tourism in South-East Asia. London: Routledge.

2009a. Introduction: "Tourism in Southeast Asia" revisited. In Tourism in Southeast Asia: Challenges and new directions, eds. Michael Hitchcock, M., King, V. T. and Parnwell, M., 1-42. Copenhagen: NIAS Press and Honolulu: University of Hawai'i Press. .eds. 2009b. Tourism in Southeast Asia: Challenges and new directions. Copenhagen: NIAS Press and Honolulu: University of Hawai'i Press. . eds. 2010. Heritage tourism in Southeast Asia. Copenhagen: NIAS Press and Honolulu: University of Hawai'i Press.

Inglis, F. 2000. The delicious history of the holiday. London: Routledge.

Keyes, C. F. 1984. Mother or mistress but never a monk: Culture of gender and rural women in Buddhist Thailand. American Ethnologist 11 (2): 223-241, https://doi.org/10.1525/ae.1984.11.2.02a00010.

Khin, T. 1980. Providence and prostitution: Image and reality for women in Buddhist Thailand. London: Change International Reports.

King, V. T. 2009. Anthropology and tourism in Southeast Asia: Comparative studies, cultural differentiation and agency. In Tourism in Southeast Asia: Challenges and new directions, eds. Hitchcock, M. King, V. T. and Parnwell, M. 43-68. Copenhagen: NIAS Press and Honolulu: University of Hawai'i Press. 2015a. Encounters and mobilities: Conceptual issues in tourism studies in Southeast Asia. SOJOURN: Journal of Social Issues in Southeast Asia 30 (2): 497-527. 2015b. Substantive and conceptual issues in tourism research: A personal engagement with Southeast Asia. International Journal of Asia Pacific Studies 11 (Supp. 1): 15-51.

2016a. Tourism development in Borneo: Comparative excursions twenty years on. Asian Journal of Tourism Research 1 (2): 63-102.

ed. 2016b. UNESCO in Southeast Asia world heritage sites in comparative perspective. Copenhagen: NIAS Press.

2017. Emerging tourisms and tourism studies in Southeast Asia. Asian Journal of Tourism Research 2 (2): 1-32.

Kontogeorgopoulos, N. 1998. Tourism in Thailand: Patterns, trends, and limitations. Pacific Tourism Review 2 (3-4): 225-238.

1999. Sustainable tourism or sustainable development? Financial crisis, ecotourism, and the "amazing Thailand campaign." Current Issues in Tourism 4 (2): 316-332.

. 2003. Keeping up with the Joneses: Tourists, travellers, and the quest for cultural authenticity in Southern Thailand. Tourist Studies 3 (2): 171-203, https://doi. org/10.1177/1468797603041631.

Leheny, D. 1995. A political economy of Asian sex tourism. Annals of Tourism Research 22 (2): 367-384, https://doi.org/10.1016/0160-7383(94)00082-4.

Li, L. and Zhang, W. 1997. Thailand: The dynamic growth of Thai tourism. In Tourism and economic development in Asia and Australia, eds. Go, F. M. and Jenkins, C. L., 286-303. London: Cassell. 
MacCannell, D. 1973. Staged authenticity: Arrangements of social space in tourist settings. American Journal of Sociology 79 (3): 589-603, https://doi.org/10.1086/225585. 1976). The tourist: A new theory of the leisure class. New York: Schocken Books.

McDowall, S. and Ma, E. 2010. An analysis of tourists' evaluation of Bangkok's performance, their satisfaction, and destination loyalty: Comparing international versus domestic Thai tourists. Journal of Quality Assurance in Hospitality and Tourism 11 (4): 260282, https://doi.org/10.1080/1528008X.2010.504181.

McDowall, S. and Wang, Y. 2009. An analysis of international tourism development in Thailand: 1994-2007. Asia Pacific Journal of Tourism Research 14 (4): 351-370, https://doi.org/10.1080/10941660903023952.

McKean, P. F. 1973. Cultural involution: Tourists, balinese, and the process of modernization in anthropological perspective. Unpublished $\mathrm{PhD}$ diss., Brown University, United States.

1976. Tourism, culture change and culture conservation in Bali. In World anthropology: Changing identities in modern Southeast Asia, ed. Banks, D., 237-247. The Hague and Paris: Mouton Publishers, https://doi.org/10.1515/ 9783110809930.

1989 [1977]. Towards a theoretical analysis of tourism: Economic dualism and cultural involution in Bali. In Hosts and guests: The anthropology of tourism, 2nd expanded ed., ed. Smith, V. L., 93-108. Philadelphia: University of Pennsylvania Press.

Manderson, L. 1992. Public sex performance in Patpong: Explorations of the edges of imagination. Journal of Sex Research 29 (4): 451-475, https://doi. org/10.1080/00224499209551662.

. 1995. The pursuit of pleasure and the sale of sex. In Sexual nature sexual culture, eds. Abramson, P. R. and Pinkerton, S. D., 305-329. Chicago and London: University of Chicago Press.

Meyer, C. A. 1988. Beyond the mask. Saarbrucken and Fort Lauderdale: Verlag Breitench.

Parnwell, M. J. G. 1993. Environmental issues and tourism in Thailand. In Tourism in South-East Asia, eds. Hitchcock, M., King, V. T. and Parnwell, M. J. G., 286-303. London: Routledge.

Peleggi, M. 1996. National heritage and global tourism in Thailand. Annals of Tourism Research 23 (2): 432-448, https://doi.org/10.1016/0160-7383(95)00071-2. 2002. The politics of ruins and the business of nostalgia. Bangkok: White Lotus. 2007. Thailand: The worldly kingdom. London: Reaktion Books.

2017. Monastery, monument, museum: Sites and artifacts of Thai cultural memory. Honolulu: University of Hawai'i Press.

Phongpaichit, P. 1982. From peasant girls to Bangkok masseuses. Geneva: International Labour Office (Women, Work and Development, 2).

Picard, M.1996. Bali: Cultural tourism and touristic culture, transl. Darling, D. Singapore: Archipelago Press.

Picard, M. and Wood, R. E. eds. 1997. Tourism, ethnicity and the state in Asian and Pacific societies. Honolulu: University of Hawai'i Press.

Reisinger, Y. and Steiner, C. J. 2006. Reconceptualizing object authenticity. Annals of Tourism Research 33 (1): 65-86, https://doi.org/10.1016/j.annals.2005.04.003. 
Rogerson, C. M. 2015. Unpacking business tourism mobilities in sub-Saharan Africa. Current Issues in Tourism 18 (1): 44-56, https://doi.org/10.1080/13683500.2014. 898619.

Rojek, C. 1995. Decentring leisure: Rethinking leisure theory. London: Sage.

Rojek, C. and Urry, J. eds. 1997. Touring cultures. London: Routledge, https://doi. org/10.4324/9780203427736.

Selwyn, T. 1993. Peter Pan in South-East Asia: Views from the brochures. In Tourism in South-East Asia, eds. Hitchcock, M., King, V. T. and Parnwell, M. J. G. 117-137. London: Routledge.

1996. Introduction. In The tourist image: Myths and myth-making in tourism, ed. Selwyn, T. 1-32. Chichester: Wiley.

Senftleben, W. 1988. The acquired immune deficiency syndrome - The case of Thailand: A new task for medical geographers. Philippine Geographical Journal 32 (2/3): $56-65$.

Sheller, M. 2011. Mobility. Sociopedia: International Sociological Association. http://www.sagepub.net/isa/resources/pdf/mobility.pdf (accessed 8 May 2017).

Sheller, M. and Urry, J. eds. 2004. Tourism mobilities: Places to play, places in play. London: Routledge.

2006. The new mobilities paradigm. Environment and Planning A 38 (2): 207 226, https://doi.org/10.1068/a37268.

Sherlock, K. 2001. Revisiting the concept of hosts and guests. Tourist Studies 1 (3): 271295, https://doi.org/10.1177/146879760100100304.

Smith, V. L. (ed.). 1989 [1977]. Hosts and guests: The anthropology of tourism, 2nd expanded ed. Philadelphia: University of Pennsylvania Press, first ed. 1977. 1989. Introduction. In Hosts and guests: The anthropology of tourism, 2nd expanded ed., ed. Smith, V. L., 1-17. Philadelphia: University of Pennsylvania Press.

Sofield, T. H. B. 2000. Rethinking and reconceptualizing social and cultural issues in Southeast and South Asian tourism development. In Tourism in Southeast and South Asia: Issues and cases, eds. Hall, C. M. and Page, S., 45-57. Oxford: ButterworthHeinemann.

2001. Globalization, tourism and culture in Southeast Asia. In Interconnected worlds: Tourism in Southeast Asia, eds. Teo, P., Chang, T. C. and Ho, K. C., 103120. Oxford: Elsevier Science, Pergamon, https://doi.org/10.1016/B978-0-08043695-1.50005-4.

Teo, P., Chang, T. C. and Ho, K. C. (eds). 2001. Interconnected worlds: Tourism in Southeast Asia. Oxford: Elsevier Science, Pergamon.

TAT (Tourism Authority of Thailand). 2017. History. www.tatnews.org/history/ (accessed 8 February, 2017).

Toyota, M. 1996. The effects of tourism development on an Akha community: A Chiang Rai village case study. In Uneven development in Thailand, ed. Parnwell, M. J. G., 226-240. Aldershot: Avebury.

Urry, J. 1990. The tourist gaze: Leisure and travel in contemporary societies. London: SAGE.

1995. Consuming places. London: Routledge.

2000. Sociology beyond societies: Mobilities for the twenty-first century. London: Routledge. 
2007. Mobilities. Cambridge: Polity Press.

Van der Duim, R. 2007. Tourismscapes: An actor-network perspective. Annals of Tourism Research 34 (4): 961-976, https://doi.org/10.1016/j.annals.2007.05.008.

Wall, G. 2001. Conclusion: Southeast Asian tourism connections - Status, challenges and opportunities. In Interconnected worlds: Tourism in Southeast Asia, eds. Teo, P., Chang, T. C. and Ho, K. C., 312-324. Oxford: Elsevier Science and Pergamon, https://doi.org/10.1016/B978-0-08-043695-1.50023-6.

Wang N. 1999. Rethinking authenticity in tourism experience. Annals of Tourism Research 26 (2): 349-370, https://doi.org/10.1016/S0160-7383(98)00103-0.

Watson, G. L. and Kopachevsky, J. P. 1994. Interpretations of tourism as commodity. Annals of Tourism Research 21 (3): 643-660, https://doi.org/10.1016/01607383(94)90125-2.

Wikipedia. 2017. Tourism in Thailand. https://en.wikipedia.org/wiki/Tourism_in_Thailand (accessed 10 February 2017).

Wilson, D. 1993. Time and tides in the anthropology of tourism. In Tourism in South-East Asia, eds. Hitchcock, M., King, V. T. and Parnwell, M. J. G., 32-47. London: Routledge.

Wood, R. E. 1979. Tourism and underdevelopment in Southeast Asia. Journal of Contemporary Asia 9 (3): 274-287, https://doi.org/10.1080/00472337985390251. 1980. International tourism and cultural change in Southeast Asia. Economic Development and Cultural Change 28 (3): 561-581, https://doi.org/10.1086/451197. 1984. Ethnic tourism, the state, and cultural change in South-East Asia. Annals of Tourism Research 11 (3): 353-374, https://doi.org/10.1016/0160-7383(84)90027-6. 1993. Tourism, culture and the sociology of development. In Tourism in SouthEast Asia, eds. Hitchcock, M., King, V. T. and Parnwell, M. J. G., 48-70. London: Routledge.

Yamashita, S. 2003. Bali and beyond: Explorations in the anthropology of tourism, transl. with introduction Eades, J. S. New York and Oxford: Berghahn Books.

Yamashita, S., Eades, J. S. and Din, K. H. 1997. Introduction: Tourism and cultural development in Asia and Oceania. In Tourism and cultural development in Asia and Oceania, eds. Yamashita, S., Din, K. H. and Eades, J. S., 13-31. Bangi: Penerbit Universiti Kebangsaan Malaysia. 